\title{
France accused of 'reneging' on promises
}

Paris. The French labour union representing scientists, - le Syndicat National des Chercheurs Scientifique (SNCS), last week called for the resignation of Guy Aubert, the director general of Centre National de la Recherche Scientifique (CNRS), over his handling of a funding crisis at the agency.

The SNCS call came during a week of protests over a long-running financial crisis at CNRS and other public research agencies. Around 1,500 researchers staged a demonstration outside CNRS's headquarters in Paris.

CNRS researchers are angry, in particular, at what they claim to be the brutal way in which the agency's management confiscated the balance on laboratory accounts at the beginning of the year - by computer transfers carried out during the night - without warning researchers beforehand. This operation left some laboratories without the funds they had set aside for long-term programmes (see Nature 380, 189; 1996).

CNRS officials have since promised to reimburse some funds that, they argue, were taken "by mistake". They have also said that funds will be advanced to laboratories that have found themselves with no money for 1996. But the agency has not said when it will make these funds available.

Adding to researchers'concerns, CNRS officials last week told a meeting of the agency's board last week that they could not guarantee that the agency would be spared from further cuts that may have to be made as part of a broader government plan to freeze FF20 billion (US $\$ 4$ million) of public spending this year.

Many scientists are claiming that the government has reneged on its promise to repay money owed to CNRS as a result of earlier budget decisions. Edouard-Henri Audier, for example, a chemist at the Ecole polytechnique, and a member of a group of laboratory directors that has just been set up to coordinate action against the cuts, argues that while the government increased CNRS's budget for running costs by FF 300 million last year, a similar sum was deducted at the same time from the salaries budget.

Researchers say they acknowledge that CNRS officials are faced with a difficult task in balancing the agency's books. But they criticize the agency for apparently supporting what they claim to be the government's failure to honour its commitments to research. They are also concerned about a freeze in recruitment. This year, public research organizations will create only eight new posts, with others being recruited in line with retirement rates - currently around 2 per cent. INSERM, for example, will only

\section{IMAGE \\ UNAVAILABLE \\ FOR COPYRIGHT \\ REASONS}

Back on the streets: CNRS researchers hold a protest meetingover government cuts.

recruit 36 researchers this year, compared with 76 in 1993.

The freeze in recruitment could not come at a worse moment. Over half the staff of the research agencies will retire before 2005 , and recruitment needs to be reinforced now if a sensible age pyramid is to be maintained. "It is not in our interest to wait until then to recruit massively" says Philippe Lazar, director general of INSERM, adding that this would inevitably also lead to a lowering of the entry standards required.

Catherine Tastemain

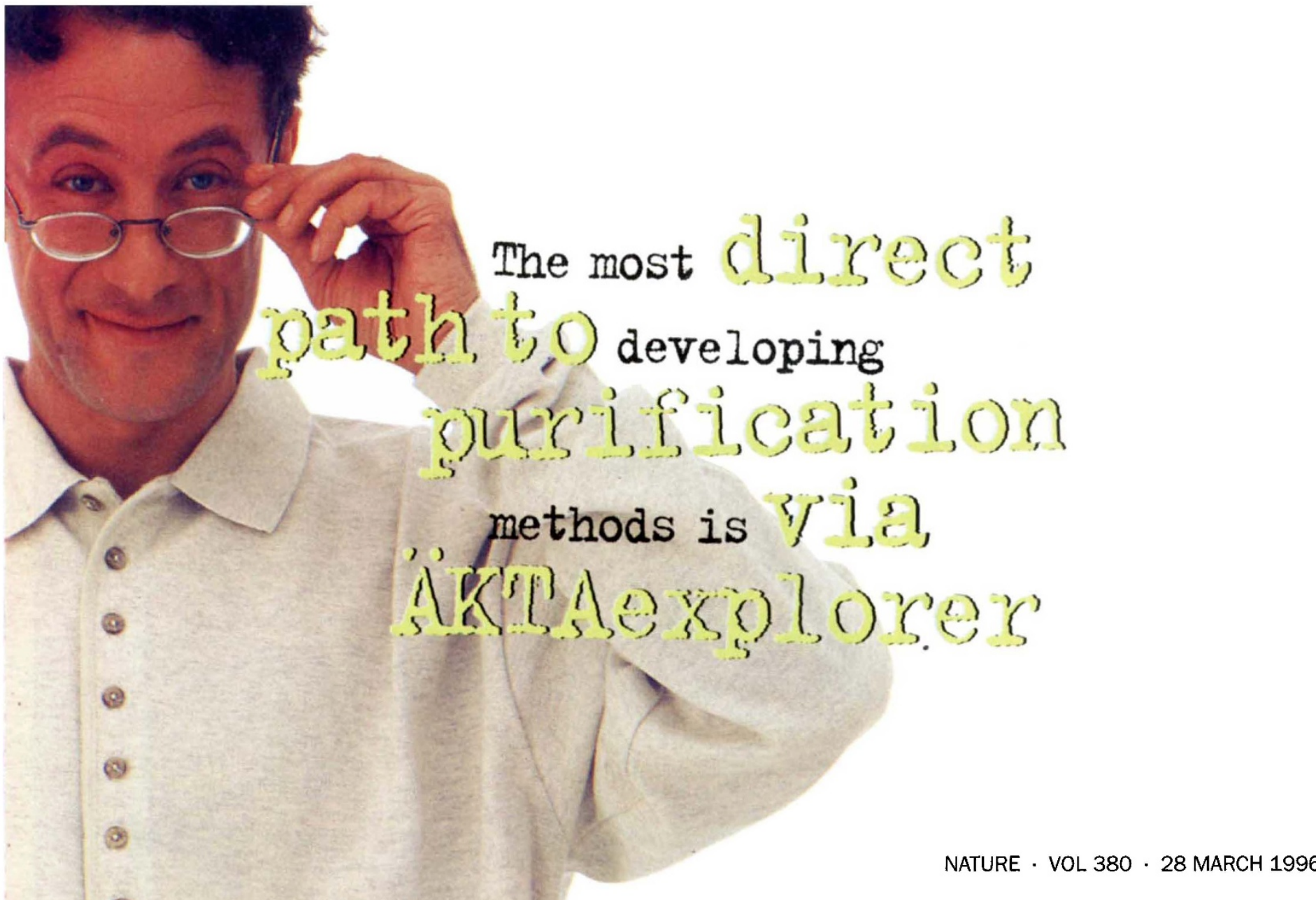

